\title{
EFFICACY OF ALGINATE EXTRACTED FROM MARINE BROWN ALGAE (SARGASSUM SP.) AS A COAGULANT FOR REMOVAL OF DIRECT BLUE2 DYE FROM AQUEOUS SOLUTION
}

VIJAYARAGHAVAN G. ${ }^{1,2}$ S. SHANTHAKUMAR ${ }^{1, *}$
${ }^{1}$ Environmental Engineering Division School of Mechanical and Building Sciences VIT University, Vellore-632014, India

${ }^{2}$ Department of Chemical Engineering AdhiParasakthi Engineering College Melmaruvathur - 603319, India

Received: 24/07/2015

Accepted: 22/09/2015

Available online: 07/10/2015 *to whom all correspondence should be addressed: e-mail: shanthakumar.s@vit.ac.in

\section{ABSTRACT}

The coagulation potential of alginate extracted from marine brown algae, Sargassum $s p$. for the removal of Direct Blue 2 dye from aqueous solution was studied. Extracted alginate was characterised by Fourier Transform Infrared Spectroscopy (FT-IR) and Scanning Electron Microscopy (SEM) techniques. Batch coagulation tests were carried out by using standard Jar test apparatus to study the influence of initial $\mathrm{pH}$ $(4-10)$, coagulant (alginate) dosage $\left(10-60 \mathrm{mg} \mathrm{l}^{-1}\right)$, initial concentration of dye $\left(100-500 \mathrm{mg} \mathrm{l}^{-1}\right)$ and calcium dosage $\left(1-6 \mathrm{~g} \mathrm{l}^{-1}\right)$ on removal of dye. The maximum dye removal was observed as $86.1 \%$ at initial dye concentration of $200 \mathrm{mg} \mathrm{l}^{-1}, 6 \mathrm{~g} \mathrm{l}^{-1}$ of calcium dose, $40 \mathrm{mg} \mathrm{l}^{-1}$ of alginate dose and $\mathrm{pH}$ 4. The Sludge Volume Index (SVI) was examined at the maximum dye removal condition and compared with Alum. The kinetic study reveals that the coagulation process for the removal of Direct Blue 2 dye follows second order kinetic model. The obtained results were compared with the literature available on the application of various seaweeds for wastewater treatment methods and their efficiency. Based on the investigation, it is evident that the alginate extracted from Sargassum sp. can be used as an effective novel coagulant for the removal of Direct Blue 2 dye from aqueous solution.

Keywords: Sargassum sp, Brown algae, Direct Blue 2 dye, Coagulation

\section{Introduction}

India has 8085 kilometres long coastal line, in which plenty of seaweed species are available. About 700 species of marine algae have been identified in the various parts of coastal line of India and nearly 60 species are commercially important (Sajid et al., 2003). The seaweeds are categorized into three types, namely the Chlorophyta (green algae), the Phaeophyta (brown algae) and the Rhodophyta (red algae). The seaweed resources are exclusively utilized for the production of commercially and industrially important phycocolloids

Vijayaraghavan G. and Shanthakumar S. (2015), Efficacy of alginate extracted from marine brown algae (Sargassum sp.) as a coagulant for removal of Direct Blue2 Dye from aqueous solution, Global NEST Journal, 17(4), 716-726. 
such as carrageenan, agar, alginates, soda ash, Alginic acid, iodine (Kaladharan et al., 1999). These phytochemicals are widely used as gelling, stabilizing, thickening agents in food, confectionary, pharmaceutical, dairy, textile, paper, paint and varnish industries. These wide variety of seaweeds were found to have a remarkable biochemical compounds that enables antibacterial, antiviral, antifungal, cytotoxic, and larvicidal potentials (Aseer et al., 2009). Certain protein rich sea weeds are used in palatable condition in the form of soup, salad, curry etc. Jelly, jam, chocolate, pickle and wafer can also be prepared from certain seaweeds. Marine algae are also used in different parts of the world as animal feed and fertilizer for crops as they contain more than 60 trace elements, carbohydrate, iodine, bromine, vitamin and some bioactive substances (Kaliaperumal et al., 1997). Apart from these uses, seaweeds have the potential for use in wastewater treatment process. Among various process oriented industries, textile industry is one of the major sources of coloured wastewater. A dye is used to impart colour to a material, of which it becomes an integral part of textile industry which affects the quality of water. Azo dyes are typically used in textile processing and paper manufacturing industries. A massive amount of azo dyes from these sources is discharged into natural waterways (Su et al., 2011). The wastewater generated from different stages of textile processing contains large quantity of pollutants can cause harmful effects to the environment if released without proper treatment. These pollutants gave several direct and indirect harmful effects like immune suppression, respiratory, circulatory, central nervous and neurobehavioral disorders presage as allergy, autoimmune diseases, multiple myeloma, leukemia, vomiting, hyperventilation, insomnia, profuse diarrhea, salivation, cyanosis, jaundice, quadriplegia, tissue necrosis, eye (or skin) infections, irritation to even lung edema (Verma et al., 2012). Ultimately the removal of dye from the textile wastewater becomes an important task and the dye removal techniques can be classified into two categories, namely Destructive and Non-Destructive (Fernandez et al., 2010) as presented in Table 1.

Table 1. Classification of dye removal techniques

\begin{tabular}{cc}
\hline Destructive methods & Non-destructive methods \\
\hline Biodegradation & Adsorption \\
Advanced oxidation processes (AOP) - Fenton & Sedimentation \\
process, Ozonation, Sonolysis, Electrochemical & Filtration \\
oxidation, Electrical discharges, Wet air oxidation & Coagulation \\
Photolysis, Photo catalysis & Electrocoagulation \\
\hline
\end{tabular}

Among all the treatment methods, Coagulation process is the simple and economical one. The detailed comparison of advantages and disadvantages of various physical and chemical process of wastewater treatment was discussed by Chuah et al., (2003). In coagulation process, selection of suitable coagulant is important, which includes considerations like availability, cost, quantity and suitability.

The coagulants like ferric chloride and aluminum sulfate (alum) for wastewater treatment were used in fullscale for several decades (Jiang J-Q, 2015). However, these conventional coagulants can cause the major problem of producing large quantity of hazardous sludge which contains metal ions that lead to harmful effects to human, animals and plants. The recent studies on coagulant reveals that the metal salts like Alum has several drawbacks, such as Alzheimer's disease associated with residual aluminum in treated water and production of large sludge volumes. It has also been reported that the reaction of aluminum with natural alkalinity present in the water leads to a reduction of $\mathrm{pH}$ and low efficiency of coagulation in cold waters. To overcome these problems involved in chemical coagulants, in the recent years the studies on natural coagulants produced or extracted from plants gain momentum (Patel et al., 2013). Hence, it becomes essential to search for a novel natural coagulant, which can be used in small quantity and produce less amount of nonhazardous sludge. In the present study, an attempt has been made to identify the coagulation potential of alginate extracted from the marine brown algae, Sargassum sp. for the effective removal of Direct Blue 2 dye from aqueous solution. 


\section{Material and methods}

\subsection{Preparation of synthetic dye solution}

Direct Blue 2 is an azo dye having a molecular formula $\mathrm{C}_{32} \mathrm{H}_{21} \mathrm{~N}_{6} \mathrm{Na}_{3} \mathrm{O}_{11} \mathrm{~S}_{3}$ and a molecular weight of $830.71 \mathrm{~g} \mathrm{~mol}^{-1}$. The dye stock solution was prepared by dissolving $1 \mathrm{~g}$ of Direct Blue 2 dye in $1 \mathrm{I}$ of double distilled water. Later, it was diluted by using distilled water as per to the concentration required and $\mathrm{pH}$ was adjusted by adding $0.1 \mathrm{M} \mathrm{NaOH}$ solution and $0.1 \mathrm{M} \mathrm{HCl}$. The synthetic wastewater samples were prepared with various initial dye concentrations of $100,200,300,400$ and $500 \mathrm{mg} \mathrm{l}^{-1}$ with different $\mathrm{pH}$ of 4, 5, 6, 8, 9 and 10. The concentration of Direct Blue 2 dye was determined by using a UV-spectrophotometer (Systronics - 119, India) at a wavelength corresponding to maximum absorbance of $611 \mathrm{~nm}$.

\subsection{Marine algae collection}

Marine Brown algae (Sargassum sp.) were collected from coastal waters (Bay of Bengal) of Mandapam ( $9.27^{\circ}$ $\mathrm{N} 79.12^{\circ} \mathrm{E}$ ), Tamil Nadu, India. Collection of samples was done by cutting the thallus with a knife near the rhizoid. The collected samples were washed with seawater in the site. The washed samples are stored in bags with ventilation before transporting it to the laboratory for further processing.

\subsection{Alginate extraction}

The sample was washed abundantly with water and dried for $30 \mathrm{~h}$ at $65^{\circ} \mathrm{C}$. Alginates were extracted by following the procedure reported by Fenoradosoa (Fenoradosoa et al., 2010). The alginate industry extraction protocol is divided into five steps: acidification, alkaline extraction, solid/liquid separation, precipitation and drying (Vauchel et al., 2008). Twenty-five grams of dried algae were soaked in $800 \mathrm{ml}$ of $2 \%$ formaldehyde for $24 \mathrm{~h}$ at room temperature, washed with water and then added to $0.2 \mathrm{M} \mathrm{HCl}(800 \mathrm{ml})$ and left for $24 \mathrm{~h}$. After which, the samples were washed again with distilled water. Alginate was extracted with $2 \%$ sodium carbonate at $100{ }^{\circ} \mathrm{C}$ for $3 \mathrm{~h}$. The soluble fraction was collected by filtration and polysaccharides were precipitated by three volume $95 \%$ of ethanol. The precipitated Sodium alginate was washed twice by $100 \mathrm{ml}$ of acetone, dried at $65^{\circ} \mathrm{C}$ and dissolved in $100 \mathrm{ml}$ of distilled water. It was then precipitated again with ethanol (v/3v) and dried at $65^{\circ} \mathrm{C}$.

The monomers present in the alginate extracted from the marine brown algae are D-mannuronic acid and Lguluronic acid (Kharkwal et al., 2012). The carboxyl groups present in the alginate can be able to react with any functional group and forms gel structure (Ikeda et al., 2000). The important characteristics of alginate are the ability to react with polyvalent metal cations and to form strong insoluble polymer gel. When alginate was interacted with calcium ion, it forms an "egg-box" structure. The coagulation process can be enhanced by any one of the following mechanism: charge neutralization along with the bridging of particles or by the gel formation of calcium and alginate. Calcium alginate gel combines with the dispersed particle irrespective of the charge and leads to flocculation (Simpson et al., 2004). Fenoradosoa et al., 2010 reported that the weight-average molecular weight and number-average molecular weight of the sodium alginate extracted from marine brown algae as $5.528 \times 10^{5} \mathrm{~g} \mathrm{~mol}^{-1}$ and $3.852 \times 10^{5} \mathrm{~g} \mathrm{~mol}^{-1}$ respectively. The pKa values of Dmannuronic acid and L-guluronic acid was reported as 3.38 and 3.65 respectively (Davis et al., 2003). The Zeta-potential (surface charge) of alginate was reported as $-60 \mathrm{mV}$ for $500 \mathrm{M}$ and $-50 \mathrm{mV}$ for $500 \mathrm{G}$ (Minami et al., 2010). The Charge density, $\theta$ of alginate gel with calcium chloride (for $M / G=1$ ) was reported as $-9.00 \times 10^{-3} \mathrm{~mol}^{-\mathrm{dm}^{-3}}$ (Inukai et al., 1999).

\subsection{Characterization of alginate}

Fourier Transform Infrared (FT-IR) Spectroscopy and Scanning Electron Microscopy (SEM) techniques were used to characterize the alginate extracted from the brown algae Sargassum $s p$. The FT-IR spectroscopy (Thermo Nicolet, AVATAR 330) was employed to determine the functional groups present in the alginate. FT- 
IR spectra was taken both for raw and dye loaded samples. The infrared spectrum of alginate was recorded as $\mathrm{KBr}$ discs in the range of $4000-400 \mathrm{~cm}^{-1}$. Scanning Electron Microscopy (TESCAN, VEGA 3) was used to characterize the surface structure and morphology of the raw and dye loaded samples of alginate.

\subsection{Experimental procedure}

A standard jar test apparatus (Dolphin CIC-304, SCIENCIL India) was employed to carry out the experiments. Calcium as calcium chloride and alginate as sodium alginate were used. The calcium dosed varied between 1 to $6 \mathrm{~g} \mathrm{l}^{-1}$ and alginate dosed varied between 10 to $60 \mathrm{mg} \mathrm{l}^{-1}$. Mixing condition for each sample employed during the experiments with following order: 5 min rapid mixing at $100 \mathrm{rpm}$ for calcium dosing, 5 min rapid mixing at $100 \mathrm{rpm}$ for alginate dosing then $20 \mathrm{~min}$ slow mixing at $40 \mathrm{rpm}$ and finally for settling $30 \mathrm{~min}$. The supernatant after sedimentation was filtered using Whatman no. 42 filter paper. The filtrate was analyzed for absorbance using UV-spectrophotometer (Systronics-119, India) at a maximum wavelength $611 \mathrm{~nm}$. The percentage dye removal was calculated by using equation (1).

Dye removal $(\%)=\frac{C_{i}-C_{f}}{C_{i}} \times 100$

Where $C_{i}$ and $C_{f}$ are the initial and final dye concentration, respectively.

The Sludge Volume Index (SVI) is the volume occupied by $1 \mathrm{gm}$ of suspension after 30 mins settling. The SVI in $\mathrm{ml} \mathrm{g}^{-1}$ was determined by following the standard method (Part $2710 \mathrm{D}$ ) prescribed by American Public Health Association (APHA, 1998) using the equation (2). At the maximum colour removal condition, the settled sludge volume after 30 min settling was determined (Part $2710 \mathrm{C}$ ) and the suspended solids concentration of a well-mixed sample of the suspension was measured (Part $2540 \mathrm{D}$ ). The same procedure was repeated for the commercial coagulant (Alum).

$$
\text { SVI }=\frac{\text { Settled sludge volume, } \mathrm{ml} \mathrm{I}^{-1} \times 1000 \mathrm{mg} \mathrm{g}^{-1}}{\text { Suspended solids, } \mathrm{mg} \mathrm{I}^{-1}}
$$

The calcium in coagulation process has ability to compress the double layer and to reduce repulsive forces between colloid/colloid, polymer/colloid and polymer/polymer pairs (Devrimci et al., 2010). In this study, the Direct Blue 2 dye is positive charge and the alginate is negatively charged. Calcium added first and alginate added next throughout this test. The initially added Calcium chloride forms free $\mathrm{Ca}^{2+}$ ions and binding the cross linkages of functional groups in the alginate polymer chain (Patel et al., 2012 and Rezende et al., 2007). In the mechanism of coagulation, the very long polymer chain molecules on the surface of particles may form loops and the end of these loops may attach with another particle, which forms a bridge between the two particles. This is the bridging mechanism of flocculation and the charges of particle and alginate do not play any important role in this mechanism (Singh et al., 2003).

\section{Results and discussion}

\subsection{FT-IR spectrum analysis}

The FT-IR spectrum of raw alginate from Sargassum sp is presented in Fig. 1 (a). A broad band at $3468 \mathrm{~cm}^{-1}$ and $3628 \mathrm{~cm}^{-1}$ was assigned to hydrogen bonded $\mathrm{OH}$. A sharp and strong absorption bond at $1612 \mathrm{~cm}^{-1}$ representing the $\mathrm{C}=\mathrm{C}$ stretch. The band at $1460 \mathrm{~cm}^{-1}$ represents the methylene $\mathrm{C}-\mathrm{H}$ stretch. A major band in the region $1708 \mathrm{~cm}^{-1}$ and $1697 \mathrm{~cm}^{-1}$ indicate the presence of a $\mathrm{C}=\mathrm{O}$ group (carbonyl group) and this confirms the nature of alginate (Fenoradosoa et al., 2010). Fig. 1 (b) represents the FTIR spectrum of sludge containing alginate and Direct Blue 2 dye. A broad band $3444 \mathrm{~cm}^{-1}$ represents the amino phenyl group which is due to the presence of Direct Blue 2 dye in the sludge (John Coates., 2000). 


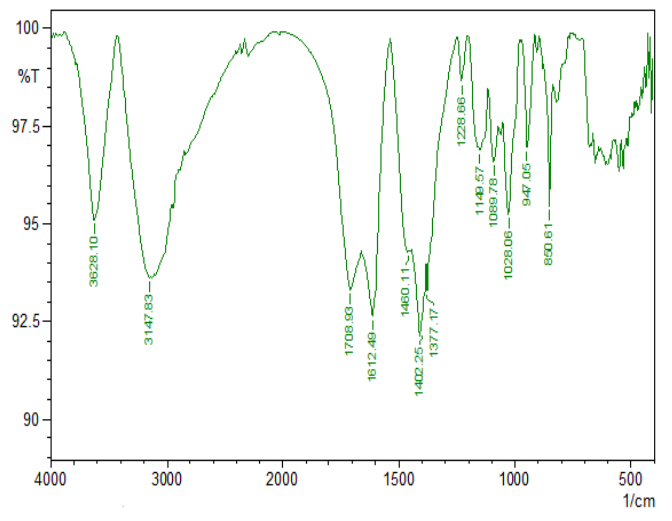

(a)

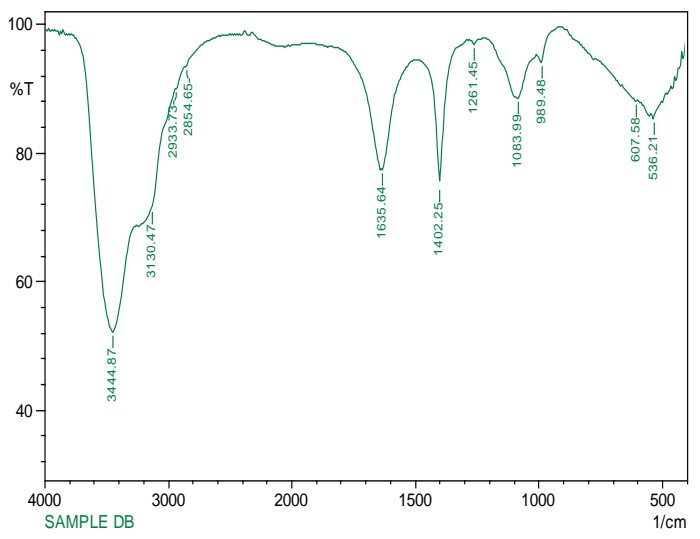

(b)

Figure 1. FTIR spectra of (a) raw and (b) dye loaded alginate

\subsection{SEM analysis}

The morphology of the raw and dye loaded alginate surface was characterized by SEM analysis. Fig. 2(a) depicts the outer layer of raw alginate which possesses fine perforations and spines on it. It can be noted from Fig. 2(b) that after coagulation, the surface of the alginate was clogged by the dye molecules.

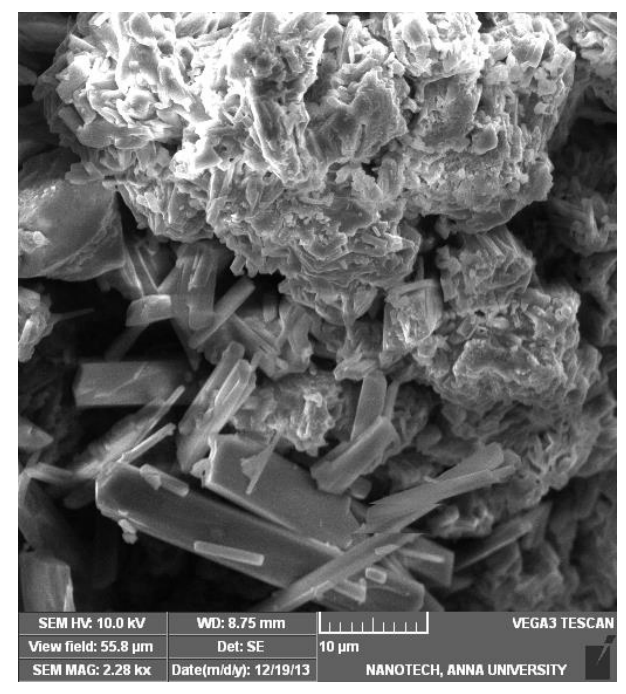

(a)

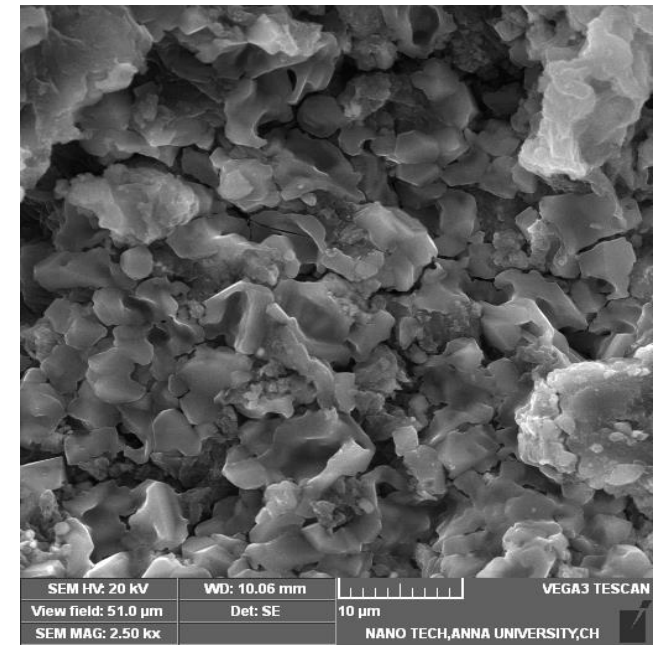

(b)

Figure 2. SEM image of alginate (a) raw and (b) after coagulation

\subsection{Effect of $p H$}

The $\mathrm{pH}$ of the system is influencing the coagulation uptake of Direct Blue 2 dye molecule due to its influence on the surface charge properties of the calcium alginate, and ionization/dissociation of the dye molecule. The maximum percentage removal of Direct Blue 2 dye was found to be $86.1 \%$ at $\mathrm{pH} 4$. The effect of $\mathrm{pH}$ on percentage dye removal is presented Fig. 3(a). 


\subsection{Effect of calcium and alginate dose}

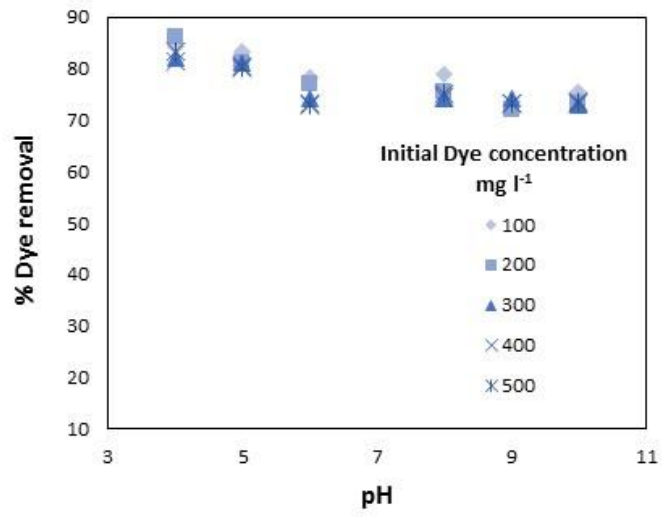

(a)

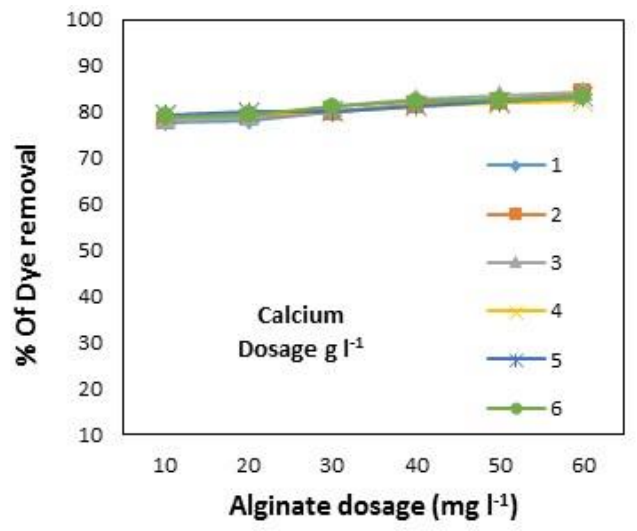

(c)

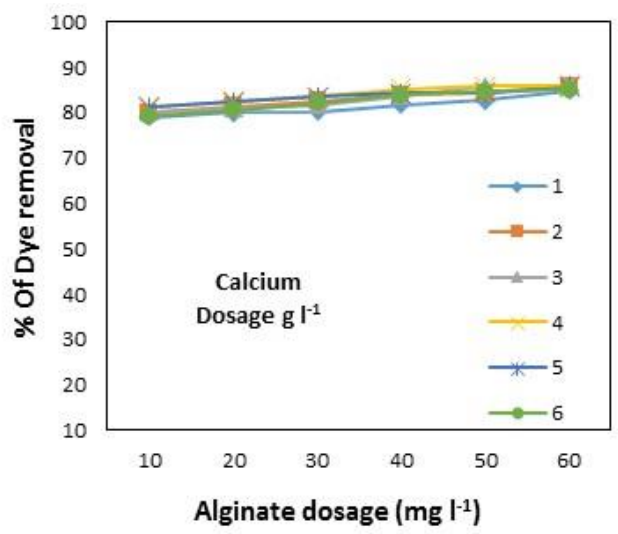

(e)

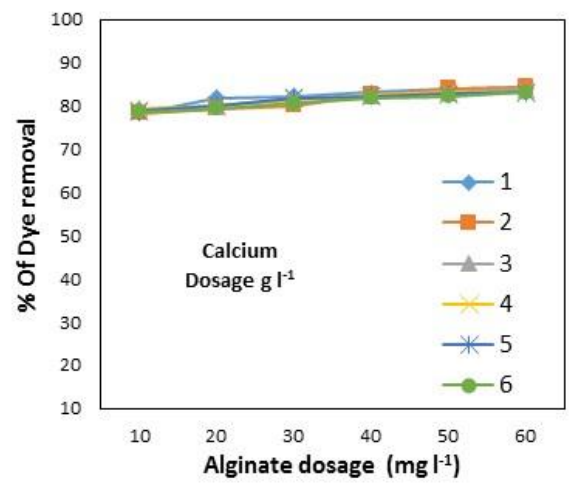

(b)

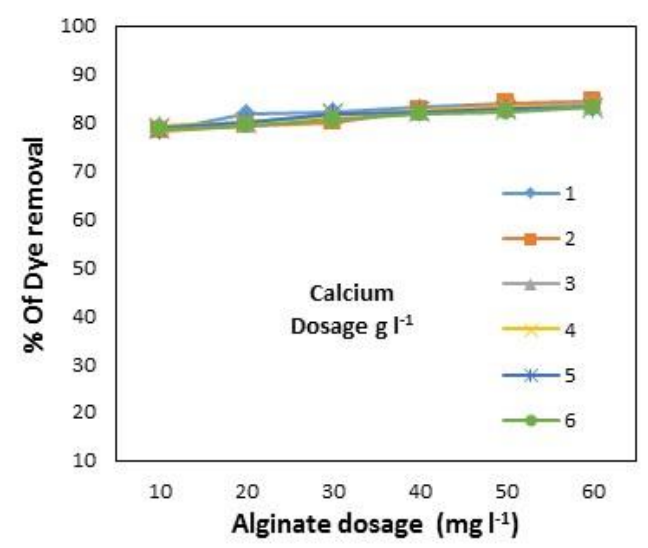

(d)

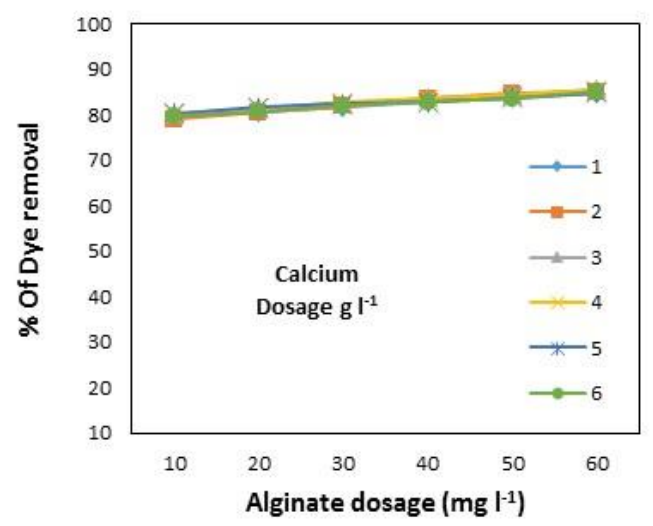

(f)

Figure 3. Effect of (a) pH and Effect of calcium and alginate dose on initial dye concentration at pH 4 (b) 100 $\mathrm{mg} \mathrm{l}^{-1}$, (c) $200 \mathrm{mgl}^{-1}$, (d) $300 \mathrm{mg} \mathrm{l}^{-1}$, (e) $400 \mathrm{mg} \mathrm{l}^{-1}$, (f) $500 \mathrm{mg} \mathrm{l}^{-1}$ 
The effect of calcium and alginate dose on dye removal was studied by varying the initial dye concentration (100 to $500 \mathrm{mg} \mathrm{l}^{-1}$ ) at $\mathrm{pH} 4$ and the results are presented in Fig. 3(b) to 3(e). It can be noted from the figures that the increase in alginate dose increases the percentage dye removal for all calcium dose levels studied. Further, it can be noted that the dye removal is significant at low initial dye concentrations (i.e., $100 \mathrm{mg} \mathrm{l}^{-1}$ ) although the calcium and alginate dose are less. However, when the initial dye concentration increases the low calcium dose is not effective in dye removal. The maximum dye removal $(86.1 \%)$ for initial dye concentration studied (i.e., $200 \mathrm{mg} \mathrm{l}^{-1}$ ) was achieved at $6 \mathrm{~g} \mathrm{l}^{-1}$ of calcium dose, $40 \mathrm{mg} \mathrm{l}^{-1}$ alginate dose and $\mathrm{pH}$ 4. During the experimentation, it was observed that the calcium alginate gel formation was not appropriate at low calcium doses. The optimum conditions for Direct Blue 2 dye removal at various initial dye concentrations at $\mathrm{pH} 4$ is presented in Table 2.

Table 2. Optimum condition for Direct Blue 2 dye removal at $\mathrm{pH} 4$

\begin{tabular}{cccc}
\hline Initial dye conc. $\mathbf{C}_{\mathbf{i}}\left(\mathbf{m g ~ l}^{-\mathbf{1}}\right)$ & Alginate dose $\left(\mathbf{m g ~ l}^{-\mathbf{1}}\right)$ & Calcium dose $\left(\mathbf{m g ~ l}^{-\mathbf{1}}\right)$ & \% Dye removal \\
\hline 100 & 30 & 6 & 84.3 \\
$\mathbf{2 0 0}$ & 40 & 6 & $\mathbf{8 6 . 1}$ \\
300 & 30 & 6 & 82.1 \\
400 & 30 & 6 & 81.3 \\
500 & 30 & 6 & 83.4 \\
\hline
\end{tabular}

\subsection{Sludge volume index}

Sludge Volume index (SVI) is commonly used to observe the settling characteristics of activated sludge and other biological suspension (Chethana et al., 2015). However, in the present study, the SVI is used to compare the performance of Alginate as a coagulant with the commercially available coagulant (Alum) in the aqueous dye solution. The SVI was obtained as $2.14 \mathrm{ml} \mathrm{g}^{-1}$ for the maximum dye removal (86.1 \%) for initial dye concentration of $200 \mathrm{mg} \mathrm{l}^{-1}, 6 \mathrm{~g} \mathrm{l}^{-1}$ of calcium dose, $40 \mathrm{mg} \mathrm{l}^{-1}$ alginate dose and $\mathrm{pH} 4$. Similarly, for the same dye removal percentage (86\%) the Alum dose was found to be $14.2 \mathrm{~g} \mathrm{I}^{-1}$ and the SVI was obtained as $16.43 \mathrm{ml} \mathrm{g}^{-1}$. Hence, it is evident from the experimental results that the quantity of sludge produced by Alum was more compared to Alginate and the alginate dose is much lower than the conventional chemical coagulant. However, it should be noted that the SVI values obtained are quite low compared to the values reported in literature which is due to the fact that in the present study, the SVI was studied in aqueous dye solution.

\subsection{Coagulation kinetics}

Coagulation kinetics for the removal of Direct Blue 2 dye using alginate as a coagulant was studied. It was observed that during coagulation process the rate of removal of dye is proportional to the initial dye concentration and the amount of calcium alginate complex. A first order and second order rate equation was examined with the experimental data (Nnaji et al., 2014). The solution for first order equation is given in equation (3)

$\log \left(\frac{C_{i}}{C_{0}}\right)=-k t$

Where $\mathrm{Ci}$ is initial dye concentration, $\mathrm{C}_{0}$ is Concentration of dye after time's' minutes and $\mathrm{k}$ is first order rate constant $\left(\mathrm{min}^{-1}\right)$.

The solution for Second order equation is given in equation (4) 


$$
\frac{1}{C_{0}}-\frac{1}{C_{i}}=k^{\prime} t
$$

Where $\mathrm{k}^{\prime}$ is second order rate constant $\left(\mathrm{mg}^{-1} \mathrm{~min}^{-1}\right)$

The plot for first and second order kinetics to the experimental data with various initial dye concentrations was shown in Fig. 4 (a) and 4 (b). From the figure, the first order equation showed higher value of intercept which clearly reveals that the coagulation process did not obey first order kinetics. Hence the coagulation process for colour removal of Direct Blue 2 dye solution using algal alginate followed a second order kinetics.

On comparing with other processes, coagulation is the very simple process where the process parameters are easily controllable. Table 3 presents the wide application of seaweed in waste water treatment at various condition and the potential usage of various seaweed extract and their effectiveness were compared with the present study. It can be noted that the alginate extracted from Sargassum seaweed has the ability to act as coagulant for the effective removal of Direct Blue 2 dye.

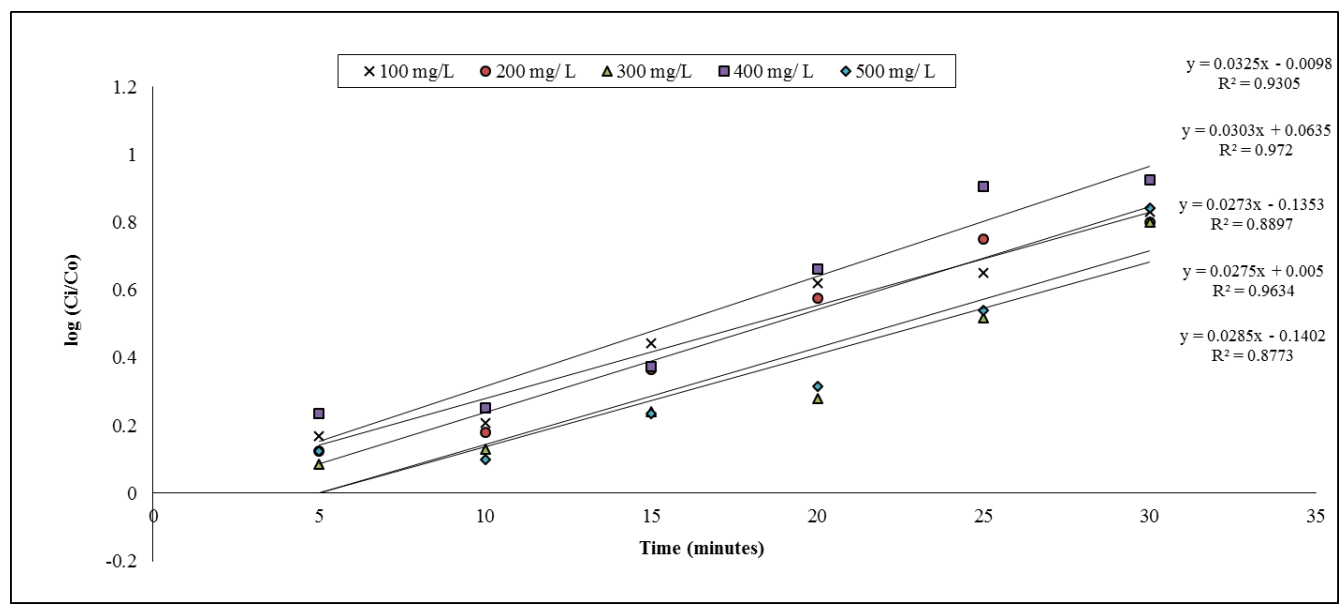

(a)

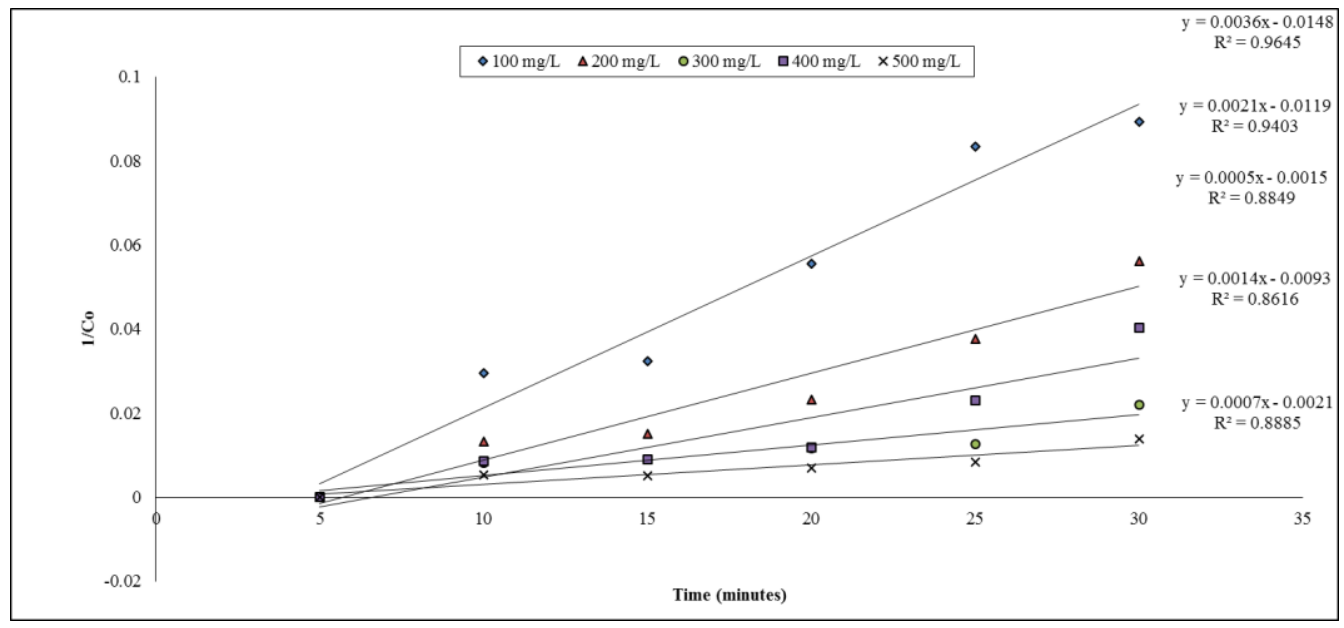

(b)

Figure 4. Coagulation kinetics plot (a) First order (b) Second order 
Table 3. Potential usage of seaweeds in waste water treatment process

\begin{tabular}{|c|c|c|c|c|}
\hline Seaweed & Treatment process & Pollutant removed & Efficiency & References \\
\hline $\begin{array}{c}\text { Protonated or Ca-form } \\
\text { Sargassum seaweed } \\
\text { biomass }\end{array}$ & Bio sorption & $\begin{array}{l}\text { Trivalent and Hexavalent } \\
\text { Chromium }\end{array}$ & $70 \%$ & David et al., 1998 \\
\hline $\begin{array}{l}\text { Sargassum binderi } \\
\text { (Brown seaweed) }\end{array}$ & Batch sorption & Basic yellow 11 & $99 \%$ & Pie et al., 2009 \\
\hline Enteromorpha & Adsorption & Malachite green & $94.74 \%$ & Jayaraj et al., 2011 \\
\hline $\begin{array}{c}\text { Amphiroa foliacea } \\
\text { (Red seaweed) }\end{array}$ & Biosorption & Reactive blue 4, & $94 \%$ & Siew-Ling et al., 2011 \\
\hline $\begin{array}{l}\text { Caulerpalentillifera } \\
\text { (Green seaweed) }\end{array}$ & Batch sorption & $\begin{array}{l}\text { acid yellow } 25 \\
\text { basic vellow } 11\end{array}$ & $\begin{array}{l}70 \% \\
98 \%\end{array}$ & Wong et al., 2011 \\
\hline Ascophyllum nodosum & $\begin{array}{c}\text { Anaerobic batch } \\
\text { digestion }\end{array}$ & Copper & $76 \%$ & $\begin{array}{c}\text { Muhammad et al., } \\
2013\end{array}$ \\
\hline Mixed algae & Adsorption & Hexavalent Chromium & $85 \%$ & Gandhi et al., 2013 \\
\hline $\begin{array}{c}\text { Isochrysis galbana } \\
\text { Chlorella.Sp }\end{array}$ & Biosorption & Textile wastewater & $55 \%$ & Mithra et al., 2012 \\
\hline $\begin{array}{l}\text { Sodium Alginate from } \\
\text { Sargassum seaweed }\end{array}$ & Coagulation & $\begin{array}{c}\text { Synthetic wastewater } \\
\text { containing Direct blue dye }\end{array}$ & $86.1 \%$ & Present study \\
\hline
\end{tabular}

\section{Conclusion}

The coagulation potential of alginate extracted from Sargassum sp. for the removal of Direct Blue 2 dye from aqueous solution was studied. The experiments were carried out in a standard jar test apparatus in order to evaluate the influence of various parameters such as $\mathrm{pH}$, initial dye concentration, calcium dose and alginate dose on dye removal. Maximum dye removal (86.1\%) was achieved with the optimum conditions as: $\mathrm{pH} 4$, alginate dose of $40 \mathrm{mg} \mathrm{l}^{-1}$, calcium dose of $6 \mathrm{~g} \mathrm{l}^{-1}$ for the initial dye concentration of $200 \mathrm{mg} \mathrm{l}^{-1}$. The Sludge Volume Index (SVI) at maximum dye removal condition using alginate as a coagulant was found to be $2.14 \mathrm{~m} \mathrm{~g}^{-1}$, whereas for the same dye removal condition, $14.2 \mathrm{~g} \mathrm{l}^{-1}$ of Commercial coagulant (Alum) was required and the SVI of Alum was found to be $16.43 \mathrm{ml} \mathrm{g}^{-1}$. The kinetic study on coagulation process showed that the process suitably fits well in second order kinetics reaction equation. It is evident from the results obtained that the alginate extracted from Sargassum sp. has the potential for the removal of Direct Blue 2 dye from aqueous solution.

\section{Acknowledgement}

The authors would like to thank VIT University, Vellore, India for providing necessary facility to carry out this research work.

\section{References}

APHA (1998), Standard Methods for the Examination of Water and Wastewater, 20th ed., American Public Health Association, Washington, USA.

Aseer M., Sugathan S., George S.K., Joseph S., Chippu S., Gandhimathi R. and Nataraja Panikkar M.V. (2009), Bio potentials of seaweeds collected from southwest coast of India, Journal of Marine Science and Technology, 17(1), 67-73.

Chethana M., Gayathri S.L., Vinay B.M., Vivek R.V. and Raja S. (2015), Application of Bio coagulant Acanthocereus tetragonous (Triangle Cactus) in dye waste water treatment, Journal of Environmental Research Development, 9, $813-821$. 
Chuah T.G., Jamasiah A., Azin I., Katayon S. and Thomas Choong S.Y. (2005), Rice husk as a potential low-cost biosorbent for heavy metal and dye removal: An overview, Desalination, 175, 305-316.

Coates J. (2000), Interpretation of Infrared Spectra, A Practical Approach, Encyclopedia of Analytical Chemistry, John Wiley \& Sons Ltd, Chichester, United Kingdom, pp.10815-10837.

David K. and Pimentel Volesky B. (1998), Removal of trivalent and hexavalent chromium by seaweed biosorbent, Environment Science Technology, 32, 2693-2698.

Davis T.A., Volesky B.A. and Muccib A. (2003), A review of the biochemistry of heavy metal biosorption by brown algae, Water Research, 37, 4311-4330.

Devrimci A.H., Yuksel M.A. and Sanin F.D. (2012), Algal alginate: A potential coagulant for drinking water treatment, Desalination, 299, 16-21.

Fenoradosoa T.A., Ali G., Delattre C., Larochevz C., Petit E., Wadouachi A. and Michaud P. (2010), Extraction and characterization of an alginate from the brown seaweed sargassum turbinarioides Grunow, Journal of Applied Phycology, 22, 131-137.

Fernandez C., Soledad Larrechi M. and Pilar Callao M. (2010), An analytical overview of processes for removing organic dyes from wastewater effluents, Trends in Analytical Chemistry, 29(10), 1202-1211.

Gandhi N., Sirisha D. and Chandra Sekhar K.B. (2013), Adsorption studies of chromium by using low cost adsorbents, Our Nature, 11(1), 11-16.

Ikeda A. and Ono T.H. (2000), Preparation of low-molecular weight alginic acid by acid hydrolysis, Carbohydrate Polymers, 42, 421-425.

Inukai M. and Yonese M. (1999), Effects of charge density on drug permeability through alginate gel membranes, Chem. Pharm. Bull., 47, 1059-1063.

Jayaraj R., Chandra Mohan M., Martin Deva Prasath R. and Hidhayathullah Khan T. (2011), Malachite green dye removal using the seaweed enteromorpha, E-Journal of Chemistry, 8(2), 649-656.

Jiang J-Q (2015), The role of coagulation in water treatment, Current Opinion in Chemical Engineering, 8, 36-44.

Kaladharan P. and Kaliaperumal N. (1999), Seaweed industry in India, ICLARM Quarterly, 22(1), 11-14.

Kaliaperumal N. and Kalimuthu S. (1997), Seaweed potential and its exploitation in India, Seaweed Research Utilisation, 19 (1\&2), 33-40.

Kharkwal H., Joshi D.D., Panthari P., Pant M.K. and Kharkwal A.C. (2012), Algae as future drugs, Asian Journal of Pharmaceutical and Clinical Research, 5, 1-4.

Minami H., Katakawa J. and Sano Y. (2010), Differences in excluded volume, diffusion coefficient, and surface charge of alginates with different Mannuronate to Guluronate ratio, J. Biol. Macromol., 10, 3-11.

Mithra R., Sivaramakrishnan S., Santhanam P., Dinesh Kumar S. and Nandakumar R. (2012), Investigation on nutrients and heavy metal removal efficacy of seaweeds, caulerpa taxifolia and kappaphycus alvarezii for wastewater remediation, Journal of Algal Biomass Utilization, 3(1), 21-27.

Muhammad M.N., Nwaedozie J.M. and Muhammed Y. (2013), Assessing the potential role of anaerobic digestion on biodegradability of copper treated biomass, Asian Journal of Natural \& Applied Sciences, 2(3), 11-19.

Nnaji N.J.N., Ani J.U., Aneke L.E., Onukwuli O.D., Okoro U.C. and Ume J.I. (2014), Modelling the Coag-flocculation kinetics of cashew nut testa tannins in an industrial effluent, Journal of Industrial and Engineering Chemistry, 20, 1930-1935.

Patel H. and Vashi R.T. (2012), Removal of Congo Red dye from its aqueous solution using natural coagulants, Journal of Saudi Chemical Society, 16, 131-136.

Patel H. and Vashi R.T. (2013), Comparison of naturally prepared coagulants for removal of cod and color from textile wastewater, Global NEST Journal, 15, 522-528.

Pie L.T., Wong C.L., Siew-Teng O. and Siew-Ling H. (2009), Equilibrium and kinetic studies for basic yellow 11 removal by sargassum binderi, Journal of Applied Sciences, 9(17), 3005- 3012. 
Rezende R., Bártolo P., Mendes A. and Filho R.M. (2007), Experimental characterisation of the alginate gelation Process for rapid prototyping, Chemical Engineering Transactions, 11, 509-514.

Sajid I.K. and Satam S.B. (2003), Seaweed mariculture scope and potential in India, Aquaculture Asia, 8(4), 26-29.

Siew-Ling H., Lesley-Lean E. and Wong C.L. (2011), Adsorption of reactive blue 4 onto the chemically modified red seaweed Amphiroa foliacea: Equilibrium, kinetics and modeling studies, International Journal of the Physical Sciences, 6(31), 7171-7182.

Simpson N.E., Stabler C.L., Simpson C.P., Sambanis A. and Constantinidis I. (2004), The role of the $\mathrm{CaCl}_{2}$-guluronic acid interaction on alginate encapsulated $\beta$ TC3 cells, Journal of Biomaterials, 25, 2603-2610.

Singh R.P., Nayak B.R., Biswal D.R., Tripathy T. and Banik K. (2003), Bio based polymeric flocculants for industrial effluent treatment, Material Research Innovations, 7, 331-340.

Su C., Pukdee-Asa M., Ratanatamskul C. and Lu M.C. (2011), Effect of operating parameters on decolorization and COD removal of three reactive dyes by Fenton's reagent using fluidized-bed reactor, Desalination, 278, 211-218.

Vauchel P., Kaas R., Arhaliass A., Baron R. and Legrand J. (2008), A new process for extracting alginates from Laminaria digitata reactive extrusion, Food and Bioprocess Technology, 1, 297-300.

Verma A.K., Roshan Dash R. and Bhunia P. (2012), A review on chemical coagulation/flocculation technologies for removal of colour from textile wastewaters, Journal of Environmental Management, 93, 154-168.

Wong C.L., Ven F.H. and Siew-Ling H. (2011), Removal of basic yellow 11 from aqueous solution by sorption on Caulerpalentillifera (Chlorophyceae), International Proceedings of Chemical, Biological \& Environmental Engineering, 18, 24-28. 